Review

\title{
Current Status of Microalgae to Produce Biogas through Pretreatment of Lignocellulosic Waste in the Era of 21- Century
}

Ali Raza Ishaq ${ }^{1}$, Faiza Jabeen ${ }^{2}$, Maleeha Manzoor*, Tahira Younis ${ }^{4}$, Ayesha Noor ${ }^{5}$ and Fatima Noor ${ }^{6}$

1 Department of Zoology, Government College University Faisalabad Punjab Pakistan; (alirazaattari476@gmail.com)

2 Department of Zoology, Government College University Faisalabad Punjab Pakistan; (acancerian@hotmail.com)

4 Department of Zoology, Government College University Faisalabad Punjab Pakistan; (tahirayounas@gmail.com)

5 Department of Zoology, Government College University Faisalabad Punjab Pakistan; (ayeshanoornoor9@gmail.com)

6 Department of Bioinformatics and Biotechnology, Government College University Faisalabad Punjab Pakistan; (fatimanoor1122@yahoo.com)

* Department of Zoology, Government College University Faisalabad Punjab Pakistan; (maleehamanzoor@gcuf.edu.pk)

\begin{abstract}
Modern day civilization is dependent on energy generation by fossil fuels. But the major drawback of using fossil fuels is environmental pollution. Microalgae are potential candidate for production of various products of interest, such as proteins, mini food, pigments and triglycerides that can be converted into biofuels. Lignocellulosic feedstocks are the most abundantly available raw material of plants that can serve as a promising feedstock for cultivating bacteria, fungi, yeasts and microalgae to produce biofuels and other value-added products. Owing to the abundant availability of these low/no cost substrates, can be utilized as feedstocks for cultivating microalgae to generate biogas/biodiesel. Likewise, there is much room to exploit defatted algal biomass to be used as animal/fish feed and oil producing/accumulating genes knowledge in future to produce high and good quality biodiesel and biogas.
\end{abstract}

Keywords: lignocellulosic substrate; pre-treatment; microalgae/cyanobacteria; biogas; problems; animal feed

\section{Introduction:}

Now-a-days energy resources are inadequate in numbers for desirable production of energy with less frugal resources [1]. Energy and Environment are included in the top ten problems of the world. To overcome these two problems, we are creating new innovative techniques to support humanity with the help of microalgae. The desirable amount of oil and other energy products are also reduced but energy requirement is reached at elevated point in this modern era. According to World Trend Plus's Association: Energy Sector in Pakistan, oil consumption was reported at 498.197 Barrel/Day in 2018. The counted value of current oil demand is about to increase $60 \%$. Fossil Fuels are non-renewable resources that are eradicated without any decomposition to acquire energy, this can cause drastic effect on economic cost of any developing country $[2,3]$. The depletion of fossil fuel is subsequent of erroring in environmental conditions such as abiotic factors such as temperature, climate, greenhouse effect $[4]$ and ultra-violet radiation $[5,6]$. 
According to reported data firstly, Chinese people used microalgae (Nostoc sp.) to overcome the famine condition about 2000 year ago [7]. We can gain energy-products via combustions, decomposition, fermentations and digestions of dead organic matter for that reason this matter is named as biomass. Biomass mainly consisted of compost and manure which may be terrestrial and aquatic [8]. Biomass feedstock is a renewable source of energy for the output of biogas [9] and biofuel through anaerobically microalgal digestion [10] as show in (Fig: 1).

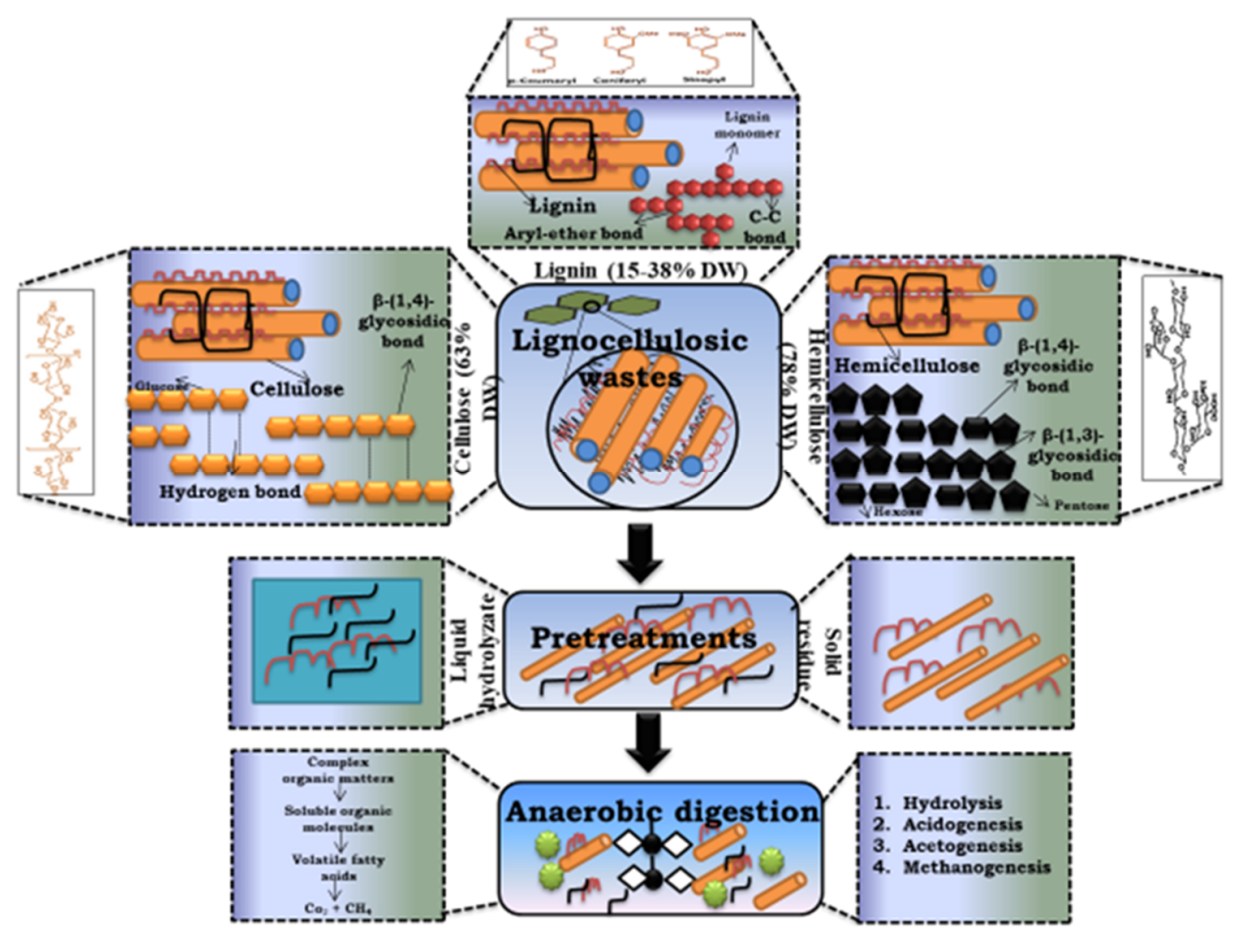

Figure 1. (Overview microalgal bio-energy products through pre-treatment of Lignocellulosic wastes)

Terrestrial biomass is a promising agent to produce renewable energy. It is relatively slow process than aquatic biomass and not affluent for financial and environmental. Aquatic biomass is most ready quickly to be produce energy on a large scale without economical cost and environmental hazards [8]. The best way to obtain high amount of energy with low economical cost is digestions and decomposition of biomass by using microalgae [11, 12].

Algae is unicellular and simple multicellular organisms with photosynthetic pigments such as chlorophyll a, b, c and other accessory pigments. Algae is multifariousness in habitat either marine or freshwater. Algae arrest high biomass output per-unit of light or area destitute of any environmental requisition [13]. Microalgal cultured acquire acoustic amount of energy without consideration [14]. The product of biomass with the help of algae are organic compounds such as lipids, proteins (such as antibiotics) and carbohydrates [15].

Microalgae has four main types based on versatile characteristics with similar to plants as it is pigmentations storehouse, photosynthetic product, collocation of photosynthetic membrane and morphological features [16]. The names of types are as Diatom, Green algae, Blue green algae and Golden algae [1]. 
There are several globally dominating species of microalgae that is advantageousness at commercial product with low cost such as Isochrysis, Chaetoceros, Arthrospira and Dunaliella [17]. Some biotechnologists suggest that microalgae have five basic types that is source of high amount of energy with low economical rate such as Dunaliella, Scenedesmus, Spirullina (cyanobacterium), Porphyridium and Chlorella over worldwide[17]. Chlorella has potency to commute its mode of nutrition due to this reason it is very influential at commercial scale $[18,19]$. Chlorella has ability to product a promising quantity of lipid that is more than $50 \%[10,20-23]$.

Algae may be autotrophic, heterotrophic and mixotrophically based on its mode of nutrition. Heterotrophic algae rely on glucose or other organic material to take advantage of carbon source. Mixotrophically algae changes its mode of nutrition season by season such as chlorella sp. and its biomolecules deviate from species to species such as carbohydrates, lipids and proteins [24]. Protein functions for animal nutrition, however, amino acid hydrolysates [25] act as to produce bacteria, yeast, as an antioxidant and use as energy source of biofertilizers [26]. Residuals biomass of microalgae are biofuel , methane $[7,9,27]$, biodiesel $[3,28]$ and bio hydrogen in a simple photobioreactor as shown in (Figure. 2) [29].

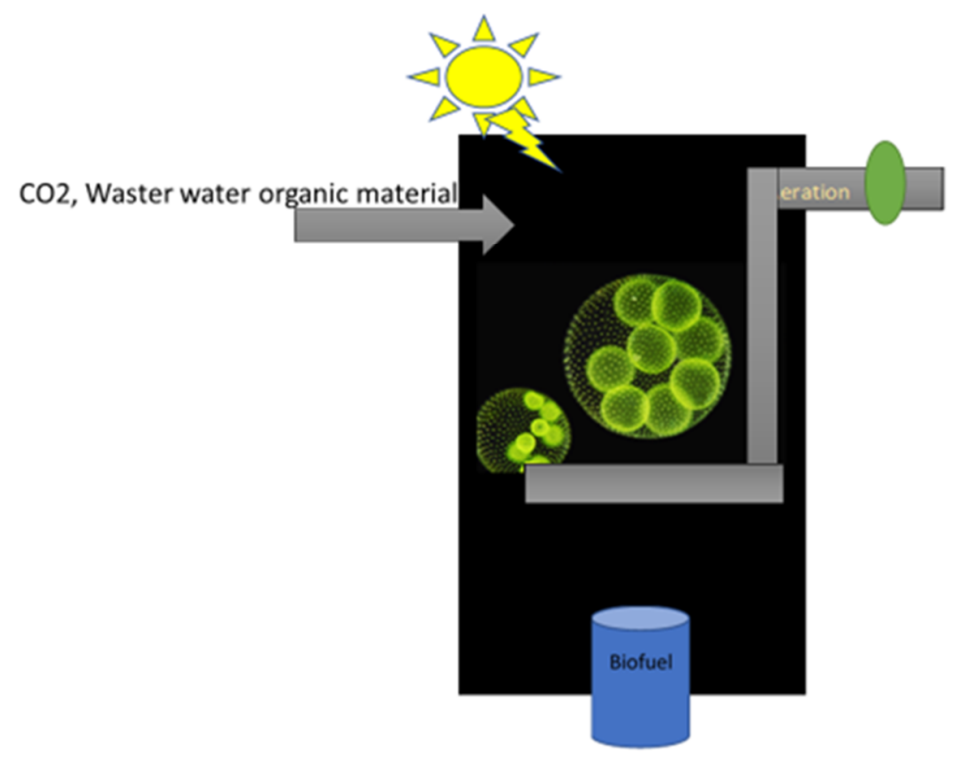

Figure 2. Photobioreactor

\section{Salient features of microalgae/cyanobacteria}

Ancient phylum of all organism is eubacteria, oxyphototrophic and cyanobacteria that are unicellular or simple multicellular [30] prokaryotic organisms, however, have ability to grow on terrestrial, lime soil, marine environment with great range of temperature [31] from arctic medium to hot spring [30]. Cyanobacteria's are in the form of colonies that brought remarkable change in biodiversity via two basic process firstly, environmental changes (converting the reducing environment into oxidizing environment by attaining photosynthesis process) and secondly, 
Endosymbiosis process (chloroplast of plants/algae evolved from endosymbiosis of cyanobacterial cell)[32]. Because of impressive morphology characters and mode of reproduction, there are five subsections i.e. Subsection I, II, III, IV, V of cyanobacteria. Subsection I and II are the spherical shape bacteria but other three subsections have filamentous type of cyanobacteria with definite mode of reproduction such as budding, fragmentation and binaryfission.

Microalgae is unicellular [33], giant multicellular that can be found in solitary cell or also group of cells and has ability to produce one half of the oxygen procreated if consuming $\mathrm{CO}_{2}$ during photosynthesis [32]. Microalgae form first trophic level in food chain, uppermost biomass producers [34] and also create interspecific relation within aquatic ecosystem [35]. The photosynthetic rate of microalga is much higher than terrestrial plant which is about $10-50 \%[36]$.

One of the most gorgeous point about microalgae is that some species are photoautotrophic (required light for growing and dispose its own food) [37] [38], heterotrophic (organic and inorganic compound is essential for its nourishment) [39] and mixotrophically (combo of autotrophic and heterotrophic) depend on the environmental conditions [32] . Due to these unique salient features of microalgae, it gives us various ecological and bioenergy advantages as show in (Table. 1)

Table 1 (Advantages of using microalgae/cyanobacteria for biogas production)

\begin{tabular}{|c|c|c|}
\hline $\begin{array}{r}\text { Sr } \\
\text { No }\end{array}$ & $\begin{array}{l}\text { Advantages of using microalgae/cyanobacteria for } \\
\text { biogas production }\end{array}$ & References \\
\hline 01 & $\begin{array}{l}\text { Microalgae/cyanobacteria can grow at high levels of } \mathrm{CO}_{2} \\
\text { throughout year }\end{array}$ & {$[12,34]$} \\
\hline 02 & $\begin{array}{l}\text { Microalgae/cyanobacteria can grow in marine/brackish, } \\
\text { freshwater and wastewaters thus less competition for } \\
\text { arable land }\end{array}$ & {$[40[41][42,43]]$} \\
\hline 03 & $\begin{array}{l}\text { Microalgal biomass is a rich source of other co-products } \\
\text { such as gasoline and biohydrogen etc. }\end{array}$ & [42] \\
\hline 04 & $\begin{array}{l}\text { Microalgae/cyanobacteria are ubiquitous and serves as a } \\
\text { promising candidate to generate high rates of } \\
\text { productivity }\end{array}$ & \multirow[t]{3}{*}[5,41]{} \\
\hline 05 & $\begin{array}{l}\text { They play important role in oxygen production. nitrogen } \\
\text { cycle and reformed the oxidizing environment from } \\
\text { reducing environment. }\end{array}$ & \\
\hline 06 & $\begin{array}{l}\text { The requirements for nourishing the } \\
\text { microalgae/cyanobacteria is very simple and prosperous } \\
\text { agent to convert the solar energy into } \mathrm{CO}_{2} \text {, also originator } \\
\text { of various feedstock for energy producing compound } \\
\text { such as lipids, carbohydrates and protein. }\end{array}$ & \\
\hline
\end{tabular}

\section{Lignocellulosic waste}

Food and plant-based waste known as lignocellulosic waste which is produced up to 1.3billions ton/year over the world [40]. Lignocellulose waste is an inexpensive and renewable energy source to produce high yield of biomass approximately 50\% [41] and carbon dioxide sequestration [42] globally throughout the year. Lignocellulose is mainly composed of hemicellulose, lignin, cellulose, phenolics [43] and other inorganic materials [44], their rate of 
production totally depends on plant species [25]. Major lignocellulosic biomass resources are manure, woodlot arising, crop residues, agro-industrial wastes, sugarcane, bagasse, sawdust and consecrated energy crop (Table. 2). The main components of lignocellulosic wastes are cellulose, hemicellulose and lignin $[45,46]$.

Table 2 (Major lignocellulosic wastes and their composition)

\begin{tabular}{|c|c|c|c|c|c|}
\hline $\begin{array}{l}\text { Sr } \\
\text { NO: }\end{array}$ & Lignocellulose wastes & $\begin{array}{l}\text { Cellulose (wt } \\
\%)\end{array}$ & $\begin{array}{l}\text { Hemicellulose } \\
\text { (wt \%) }\end{array}$ & $\begin{array}{l}\text { Lignin } \\
\text { (wt \%) }\end{array}$ & References \\
\hline 01 & Corn stalks & 35.0 & 16.8 & 7.0 & [14] \\
\hline 02 & Sugarcane bagasse & 40.0 & 27.0 & 10.0 & \\
\hline 03 & Wheat straw & 32.9 & 24.0 & 8.9 & \\
\hline 04 & $\begin{array}{l}\text { Soft wood } \\
\text { (spruce) }\end{array}$ & 44.7 & 22.9 & 30.6 & [51] \\
\hline 05 & $\begin{array}{l}\text { Hard wood } \\
\text { (beech) }\end{array}$ & 45.6 & 25.9 & 23.8 & \\
\hline 06 & Grass (switch grass) & $32.2 \%$ & $24.4 \%$ & $23.3 \%$ & \\
\hline
\end{tabular}

\section{Cellulose:}

Cellulose is most abundant polysaccharide in biosphere and chief ingredient of higher plants, brown, red and green algae. Cellulose is unbranched polymer, formed by monomer of glucose that are linked by $\beta$ - 1,4- glycosidic bond. Its degree of polymerization is about to $14000-$ 15000 glucose monomer each monomer rotates at $180^{\circ}$ angle.

\section{Hemicellulose:}

The second most nature-gifting polymer in this biosphere is hemicellulose which has random and amorphous structure, consisted of heteropolymer such as xyloglucan, glucomannan, arabinoxylan, glucuronoxylan, galactomannan and xylans [47]. Due to this, its chemical composition deviated from species to species, however, xylans and glucomannan are present in hard wood or soft wood respectively[47]. Hemicellulose makes up $15-35 \%$ plant biomass that are joined with cellulose by hydrogen bond, to lignin through covalent bond

\section{Lignin:}

Lignin are large, complex and crosslinked aromatic polymers that are formed by oxidative combinative conjugation of 4- hydroxy-phenyl-porpanoids [48]. Lignin monomers are linked together through C-C and aryl ether linkage associating with varieties of functional group such as methoxy, phenolic hydroxy and adjacent aldehyde [49]. Divergence in composition of bond and functional group depend on the plant's species biomass. Lignin provide strength and protect from stress condition by association with cellulose and hemicellulose.

\section{Pre-treatment of lignocellulosic waste:}

Pre-treatment is a critical procedure for the biochemical renovation of lignocellulosic biomass into bioethanol, biogas, biohydrogen [50]. This process is essential to modify the cellulosic biomass for making large quantity of cellulose which is converted into the carbohydrate polymers (fermentable sugars) by the action of specific enzymes [51]. Pre-treatment of lignocellulosic wastes is completed through the acidic, 
basic and enzymatic courses [46]. Recent researches reveal that enzymatic hydrolysis is best-identified technique to get high yield of biomass (Fig. 3).

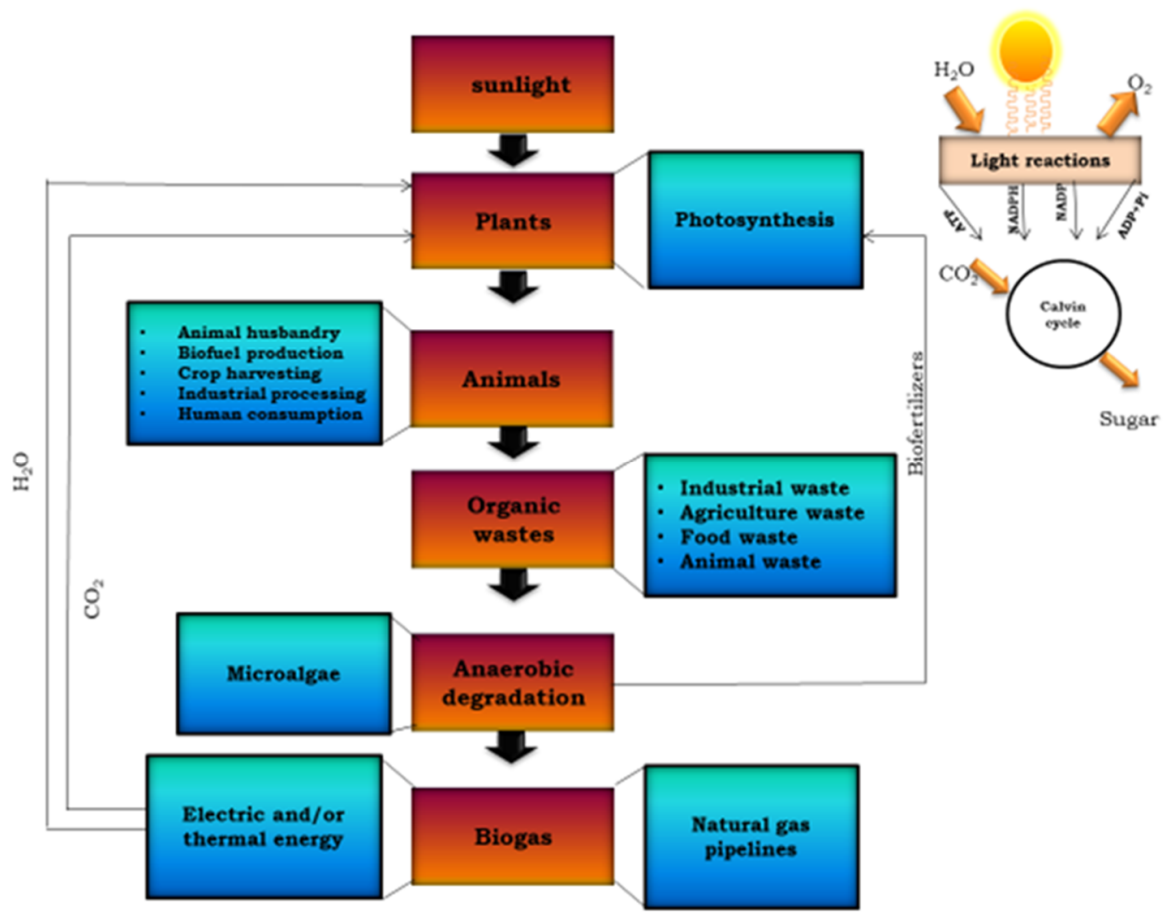

Figure 3 (Schematic representation of pre-treatment of lignocellulosic biomass procedure)

\section{Acidic Method:}

Acidic method is one of the superlative methods to treat the lignocellulosic wastes through weak or strong acid hydrolysis specifically dilute acid hydrolysis that is most operative dealing to gain high yield of biogas [25] . There are two types of weak acid hydrolysis usually:

- Extreme temperature and unceasing stream course for low solids loading ( $\mathrm{T}>160{ }^{\circ} \mathrm{C}, 5-10 \mathrm{wt} \%$ substrate concentration).

- Low temperature and consignment method for high solids loading $\left(\mathrm{T} \leq 160{ }^{\circ} \mathrm{C}, 10-40 \%\right.$ substrate concentration).

Dilute $\mathrm{H}_{2} \mathrm{SO}_{4}$ is putted on the underdone material and mixture is held at $160-220{ }^{\circ} \mathrm{C}$ for few minutes. After providing these ailment, hydrolysis of hemicellulose is started, liberate monomeric sugars and soluble oligomers into the hydrolysate by the matrix of cell wall. Hemicellulose exclusion rises sponginess of mixture that progresses the enzymatic digestibility, with extreme enzymatic digestibility typically with whole hemicellulose removal. In place of substitute to inorganic acids, organic acids such as maleic acid, fumaric acid can also be used for dilute acid pre-treatment. The hydrolysate produced is a mixture of various valuable organic carbon, in the form of sugars, acts as a potential source to support microalgal growth and production of other targeted compounds such as oil and pigments [43].

This treatment proposals good routine in standings of recovering hemicellulose sugars but also faces nearly disadvantages. The dangerous deprivation of hemicellulose bounces us strong inhibitor molecules to microbial fermentation such HMF and furfural. In addition, acids can be corrosive and induce 
neutralization consequences in the construction of solid waste for treating the low lignin content holding biomass because elimination of lignin from biomass is practically insignificant.

Treatment of lignocellulosic material with concentrated strong acids such as $\mathrm{H}_{2} \mathrm{SO}_{4}$ and $\mathrm{HCl}$ have been extensively used since they are powerful agents for cellulose hydrolysis with less enzyme requirement. Some advantages of using concentrated acid hydrolysis are the suppleness in terms of feedstock choice, high monomeric sugar yield as well as slight temperature conditions that are required. Drawbacks of this method are damaging natural cycles (Carbon, Nitrogen and water cycle) so, we can be controlled this damaging by recycling of acids in order to lower cost. Strong acid hydrolysis of lignocellulosic biomass in the process of commercialising for microbial fermentation resolves through countless corporations [52].

\section{Alkaline Method:}

To rally the reactivity of residual polysaccharides done by alkaline pre-treatment by elimination of lignin from biomass. Another advantage of alkali pre-treatment is removal of acetyl group and innumerable uronic acid replacements on hemicellulose that lesser the approachability of the enzyme on hemicellulose and cellulose surface. The saponification of intermolecular ester bonds crosslinking xylene hemicelluloses and other gears such as lignin are basis of alkaline hydrolysis processes. Habitually, three bases are castoff in lignocellulosic pre-treatment for acquisition of high energy amalgams such as biogas, biohydrogen and methane etc.

i. $\quad$ Calcium Hydroxide

ii. Sodium Hydroxide

iii. Ammonia

$\mathrm{Ca}[25]_{2}$ and $\mathrm{NaOH}$ are the most commonly used bases for lignocellulosic biomass pre-treatment. The time of reaction is too extensive but mild environments are provided to the procedure due to this condensation of lignin is stopped that is helpful for high solubility of lignin in low lignin content biomass such as softwood and grasses etc. Mild conditions have other advantages to limit the degradation of sugar into inhibitors of biomass such HMF and furfural. Providing aeration will enhance the process of delignification of high lignin biomass.

Pre-treatment of biomass with ammonia is ended by providing the aqueous ammonia with high temperature that decline the lignin contents and eradicate few hemicellulose during recrystalising cellulose compound. This method comprises the ammonia fibre explosion-method (AFEX), ammonia recycle percolation (ARP) and soaking in aqueous ammonia (SAA). Lignocellulosic biomass must be discoloured through microbial enzymes which perform output chemical hydrolysis because enzymes demonstrate the high substrate and reaction specificity, activate beneath minor circumstances and not produce by-products [49]. Due to this enzymatic method is precious for chemical, fuel, food and textile industries as well as in washing powder constructions and in paper making [46] (Table. 3).

Table 3 (Effect of Biogas production through various Pre-treatment methods)
Sr. Pre-
Enhancement Advantage
of Biogas \%
Disadvantage
References
No treatment method 


\begin{tabular}{|c|c|c|c|c|c|}
\hline 01 & Acidic & $0-166$ & $\begin{array}{l}\text { Destruction of } \\
\text { lignin and } \\
\text { hemicellulose }\end{array}$ & $\begin{array}{l}\text { High charge of } \\
\text { acid } \\
\text { - } \begin{array}{l}\text { Deterioration } \\
\text { problem }\end{array} \\
\text { in digester } \\
\text { - Establishment of } \\
\text { inhibitory } \\
\text { substance }\end{array}$ & [58] \\
\hline 02 & Basic & $0-207$ & $\begin{array}{l}\text { Solubilizes the } \\
\text { lignin and } \\
\text { hemicellulose }\end{array}$ & $\begin{array}{ll}\text { - } & \text { High alkali } \\
\text { meditation in } \\
\text { digester } \\
\text { - } \\
\text { Elevated cost of } \\
\text { chemical }\end{array}$ & \\
\hline 03 & Enzymatic & $0-208$ & $\begin{array}{l}\text { Low energy } \\
\text { feasting }\end{array}$ & $\begin{array}{l}\text { - Unceasing adding } \\
\text { mandatory } \\
\text { High cost of } \\
\text { enzymes }\end{array}$ & [59] \\
\hline
\end{tabular}

\section{Wastes water Treatment}

The quantity of wastewater production every day is gigantic because growing population and swift industrialization in any developing country. Due to this, water pollution is one of the greatest lifethreatening environmental problem $[53,54]$. Countless number of methods are adopted for treating the wastewater that cause pollution in environment, all of these are overpriced and not economical but one of the best methods for treating wastewater by microalgae that is economical and eco-friending. This method is also known as microalgae-based wastewater treatment (MBWT)[55]. One of the greatest advantages of this method to switch pollution in atmosphere because microalgae has capability to remove heavy metals, inorganic ions and other organic material [56]. Following types of wastewater are being treated by applying/cultivating microalgae.

\section{Sewage wastewater:}

Sewage wastewater treatment is ironic foundation of carbon, nitrogen and phosphorous compounds but when we cultivate algae on such sort of water, the subtraction of nitrogen efficiency was declined [57]. After sophisticated euglenoid growth displays that distinct kind of carbon eradicate by algal assimilation concluded swift lessening in the suspended solids [57].

\section{Municipal Wastewater:}

Households, commercial events and industrial facilities are superlative basis for creating the municipal wastewater with high organic contents, nitrogen and phosphorous. This type of water is annoying with dock noxious compounds and pathogenic microorganisms that's why municipal wastewater must be treated with microalgae before reprocessing to the environment. Microalgae farming is being recorded broadly functional for removal of nitrogen, phosphorous [23,58] and other toxic 
compounds. One of the superior advantages of using microalgae is that it is most attainable for biodiesel production or also act as assistant for eradicating the nitrogen and phosphorus [59].

\section{Industrial wastewater:}

Industrial water is the best source of organic Carbon or $\mathrm{CO}_{2}$ for mixotrophic and autotrophic gardening of microalgae must be utilized for biodiesel creation through any category of waste, but industrial wastewater is elevated source of minerals that is required for microalgae cultivation [5]. Agroindustrial wastewater is best source for microalgae growth because the waste of domesticated or nondomesticated animals is best medium or pitch for microalgae growth especially chlorella sp. $[15,60]$ (Table. $4)$.

Table 04 (Methane and biogas yield of some microalgae species by using wastewater)

\begin{tabular}{|c|c|c|c|c|c|c|}
\hline Species & $\begin{array}{l}\text { Optimum } \\
\text { Temperature } \\
{[66]}\end{array}$ & $\begin{array}{l}\text { Reactor } \\
\text { type }\end{array}$ & $\begin{array}{l}\text { Type of } \\
\text { Waste(s)/ } \\
\text { Water }\end{array}$ & $\begin{array}{l}\text { Methane (L } \\
\mathrm{CH}_{4} \mathrm{~g} / \mathrm{VS} \text { ) }\end{array}$ & $\begin{array}{l}\text { Biogas Yield } \\
(\mathrm{ml} / \mathrm{gVS})\end{array}$ & References \\
\hline $\begin{array}{c}\text { Spirulina } \\
\text { platensis }\end{array}$ & 30 & $\begin{array}{l}\text { CSRT/Semi } \\
\text { continuous/ } \\
\text { Batch }\end{array}$ & $\begin{array}{l}\text { Sewage } \\
\text { Sludge }\end{array}$ & $0.26-0.32$ & $\begin{array}{l}525-640 \\
\mathrm{ml} / \mathrm{gVS}\end{array}$ & [67] \\
\hline Chlorella vulgaris & $28-31$ & Batch & $\begin{array}{l}\text { Domestic } \\
\text { and } \\
\text { Municipal } \\
\text { wastewater }\end{array}$ & $0.31-0.35$ & $238-99 \mathrm{ml} / \mathrm{gVS}$ & [66] \\
\hline Chlorella sp. & 35 & Batch & $\begin{array}{l}\text { Seafood } \\
\text { Processing }\end{array}$ & $0.17-0.32$ & $\begin{array}{l}44 \mathrm{ml} \mathrm{CH}_{4} / \mathrm{gVS} \\
\text { (from chlorella } \\
\text { sp.) } \\
193 \mathrm{ml} \\
\mathrm{CH}_{4} / \mathrm{gVS} \\
\text { (from } \\
\text { processing of } \\
\text { Seafood }\end{array}$ & [65] \\
\hline $\begin{array}{r}\text { Scenedesmus } \\
\text { obliquus }\end{array}$ & $35-37$ & Batch & $\begin{array}{l}\text { Secondary } \\
\text { waste } \\
\text { effluents and } \\
\text { Municipal } \\
\text { wastewater, } \\
\text { urban } \\
\text { wastewater }\end{array}$ & 0.18 & $\begin{array}{l}346 \mathrm{~L} \mathrm{CH}_{4} / \mathrm{Kg} \\
\mathrm{VS} \\
287 \mathrm{ml} / \mathrm{gVS}\end{array}$ & [68-70] \\
\hline $\begin{array}{r}\text { Chlamydomonas } \\
\text { reinhardtii }\end{array}$ & 38 & Batch & $\begin{array}{l}\text { Wastewater } \\
\text { at different } \\
\text { level of } \\
\text { treatment }\end{array}$ & 0.39 & $587 \mathrm{ml} / \mathrm{gVS}$ & {$[60,69]$} \\
\hline $\begin{array}{r}\text { Botrycoccus } \\
\text { braunii }\end{array}$ & 35 & Batch & $\begin{array}{l}\text { Secondary } \\
\text { treated }\end{array}$ & $\begin{array}{l}404 \mathrm{~mL} / \mathrm{CH}_{4} \\
\text { g VS }\end{array}$ & $614.11 \mathrm{~L} / \mathrm{kg}$ & $\begin{array}{l}{[71,72]} \\
{[73]}\end{array}$ \\
\hline
\end{tabular}




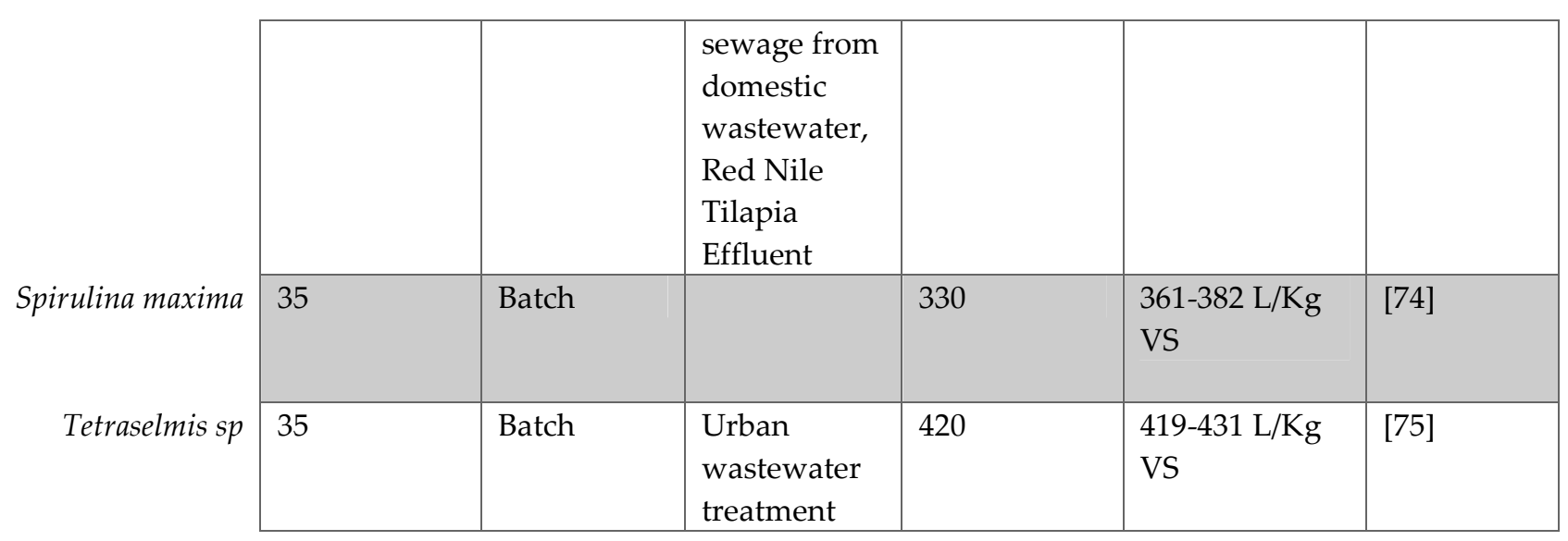

\section{Favourable conditions for microalgae/cyanobacteria}

Reduction of fossil fuels, high energy mandate, environmental fluctuations and elevated requirement of oil prices researchers focus for an alternative source of biofuel. Another alternative source of biofuel is algal fuel due to feedstocks are much more consistent by using them, our dependency on fossil fuel will be decreased [26]. Both quantitative and qualitative characteristics of lipids content in algal cell biomass will fluctuate due to variable growth conditions such as temperature, $\mathrm{pH}$, light intensity and nutrition media (concentration of nitrogen, iron, phosphate and other inorganic molecules) [10,28]. The cultivation is also effected by some other biotic factors such as pathogens and presence or absence of other algal species [61].

\section{- Effect of temperature:}

The consequence of temperature on microalgae growth display significant distinction due to this they cultivate in impulsive temperature series [62]. Researchers found that optimal temperature for microalgal growth is $20-30^{\circ} \mathrm{C}$ although they can also develop in constant temperature. When temperature is $16^{\circ} \mathrm{C}$ than they illustrate minimum growth not at very high rate, temperature is elevated above $16-20^{\circ} \mathrm{C}$ than growth is amplified.

The growth must be increased at significant rate at $20-24^{\circ} \mathrm{C}$ and increased at $28^{\circ} \mathrm{C}$. The microalgal growth rate is affected at $30^{\circ} \mathrm{C}$, decreased at $32^{\circ} \mathrm{C}$ and almost $17 \%$ decline growth rate at $35^{\circ} \mathrm{C}$ [38]. When temperature is above the optimal temperature about $38^{\circ} \mathrm{C}$ that led to death of algal cell biomass due to denaturation of protein [31, 33].

\section{- Effect of $\mathrm{pH}$ :}

Microalgae grow in variable ranges of $\mathrm{pH}$ revealed significant effect on it but the optimal $\mathrm{pH}$ for microalgae is 7-8 $\mathrm{pH}$ level to show maximum growth rate [63]. Researchers observed that growth must be influenced by different ranges of $\mathrm{pH}$ such as at $6.5 \mathrm{pH}$ microalgae growth rate is low but at 7-8 $\mathrm{pH}$ level show fastest growth rate [64]. When $\mathrm{pH}$ is above optimal rate about 9 than they show continuously declined growth rate. It is also found that $\mathrm{pH}$ very sensitive to sustain the growth of microalgae that's why it estimated that $\mathrm{pH}$ is third most important factor (after temperature and light intensity) for microalgae growth $[16,37,38]$.

\section{- Effect of light:}

Diverse form lights coming from different sources can be categorized as direct sunlight, indirect sunlight, fluorescent light and under dark, effect the remarkable fluctuations in growth rate of microalgae $[44,65]$. Under dark conditions, microalgae growth is not documented since 
light is crucial constituent for their growth and microalgal culture is set near to the window than it expresses roughly extent of growth [58].

In case of direct sunlight, they give us maximum rate of growth specifically fluorescent light if we provided, microalgae growth rate is at elevated level so that's why light has significant effect on microalgal growth. Microalgae growth is also depended on light intensity, exposure and penetration so at high light intensity damages the composition of their pigments (phycobilin and phycoerythrin _ their nature different from other plant pigments based on molecular structure and absorption of light) due to this microalgal growth also effected $[44,62,65]$.

\section{- Effect of Aeration:}

Continuous aeration is an essential factor unicellular form of algae (Chlorella sp.) growth that's why without any mean of aeration, no more growth is recorded due to death of microalgae biomass cell. Scientists use the aeration mechanism, or several means of aeration in photobioreactor for better growth and elevated amount algal fuel [39].

Microalgae are best agents for production of biogas in case of low economical value for obtaining large quantity of bio-products [66]. Thus, able to overcome the energy crisis and used as bioindicator and for bioremediation.

\section{Inhibitor as by - Product of Lignocellulosic waste treatment:}

Inhibitors are those compounds which can stop or slow a biochemical process that may be competitive or non-competitive inhibitors. The by-product of pretreatment depends on the nature of chemical reaction and type of method which we use. Inhibitors can stunt the growth of microorganism such as phenolic compound, aromatics, aliphatic acid, furan aldehydes, inorganic ions and other bioalcohols [52, 67, 68].

\section{Phenolic Compound:}

We draw out phenolic compound during the pretreatment of lignin and wood extractives. Phenolic compounds are long-familiar with inhibiting activity against microorganism due to various strains of microalgae show the various responses against these types of compounds. Some microalgae/cyanobacteria show complete resistant against phenolic compounds such as Chlorella saccharophila, Scenedesmus quadricauda, Chlorella zofingiensis, Coelastrum microporum and Mesotaenium caldarorium [43].

\section{Furans:}

Furans are union of furfural and Hydroxymethyl furfurals (HMF) that are producing during the pretreatment of sugar and lignocellulosic at dilute medium [69]. Knowledge about the effect of furans on microalgae growth is scarcely but their peculiar amount of furfural and HMF stimulate the inhibition of growth and ethanol production in diverse species of microalgae such as Saccharomyces cerevisiae, Zymomonas mobilis, Pichia stipites and Candida shehatae.

\section{Levulinic Acid:}

Levulinic acid is produced by the segmentation of HMF and its inquisitive amount $1.16 \mathrm{~g} / \mathrm{L}$ stunt the growth of microalgae by synthesis the chlorophyll in various species microalgae i.e Sceletonema costatum, Chlorella vulgaris and Agmenellum quadruplicatum [69]. 


\section{Fatty acid:}

Fatty acids are powerful part of lignocellulose waste material that are constitute of wood of various trees such as Eucalyptus. Fatty acids are also act as inhibitory agent in various species but their peculiar types such as oleic acid, palmitic acid and linoleic acids are major inhibitory effect on diverse species such as S. capricornutum, Monoraphidium contortum and Chlorella vulgaris [43].

\section{Biogas productivities}

Microalgal species required specific medium for its growth or normal functioning on the substrate to produce large quantity of biogas yield or productivity [70] [71]. These are also helpful for treating the agro-industrial wastes to reduce the pollution in an environment for sustaining the life on this (Table. 5).

Table 5 (Microalgal Biogas Yield and Biogas productivity)

$\begin{array}{cclc}\text { Sr. No Microalgae } & \text { Biogas yield ml/g } & \begin{array}{l}\text { Biogas } \\ \text { Productivity (P) } \\ \text { Dl/1V }\end{array} & \text { References } \\ & & \end{array}$

\begin{tabular}{l|l|l|l|l|}
01 & Desmodesmus.sp & 456 & 1436.40 & [12] \\
\cline { 2 - 4 } 02 & D. armatus & 440 & 1318.53 & \\
\cline { 2 - 4 } 03 & H. pluvialis & 413 & 1261.63 & \\
04 & S. obliqus & 433 & 548.47 & \\
05 & C. vulgaris & 510 & 1944.80 & \\
06 & C. sacharophilum & 303 & 887.79 & \\
\cline { 2 - 4 } 07 & Geminella.sp. & 448 & 981.12 & [40] \\
08 & G. terricola & 316 & 449.77 & \\
09 & P. tricornutum & $0.337 \mathrm{~L}$ & - & [84] \\
\cline { 2 - 4 } 10 & Isochrysis galbana & $0.22 \mathrm{~L}$ & - & \\
11 & Scenedesmus sp. & 646 & - & \\
12 & Chlorella sp. & 652 & - & \\
\cline { 2 - 4 } 13 & Cladophora glomerate & $0.20 \mathrm{~m}^{3} / \mathrm{m}^{3} \mathrm{~d}$ & - & \\
\cline { 2 - 4 } 14 & Chara fragilis & $0.12 \mathrm{~m}^{3} / \mathrm{m}^{3} \mathrm{~d}$ & - & \\
\cline { 2 - 4 } 15 & Spirogyra neglecta & $0.23 \mathrm{~m}^{3} / \mathrm{m}^{3} \mathrm{~d}$ & - & \\
\cline { 2 - 4 } & & & & \\
\cline { 3 - 4 } & & & & \\
\end{tabular}

\section{Problems associated with anaerobic digestion of microalgae}

Anaerobic digestion is not superlative known or beneficial method because a lot of complications fashioned during dealing out with micro-algae biomass for gaining a huge bioenergy product by means of agro-industrial wastes [72]. Some of the challenges are:

\section{Low concentration of digestible substrate}

Microalgae biomass is ironic font for acquisition high dynamism foodstuffs with lower commercial rate or low economically rate. Micro-algae with low volatile solid piling quantity can be utilized as digestible substrate for mining out less concentration of biomass in high volume of water [64].

\section{Cell wall degradability:}


Cell wall degradability is foremost matter for anaerobic digestion because its conformation stuff the production of biogas during processing of microalgae some compounds were remained undigested [64, 73]. Impregnation of carbohydrates and supplementary biomolecules make the cell wall extra rigid and absenteeism or less amount of these molecules make not as much of rigid. Biogas production hang on rigidity of cell wall, its means micro-algae with stronger rigidity of cell wall produce less amount biogas but absence of this type cell wall microalgae gives out a measurable amount of biogas [74].

Lower productivity of biogas from cell wall microalgae, motive is that cell wall provide housing to microalgae from bacteria and guard inner organic material [72](Fig. 04).

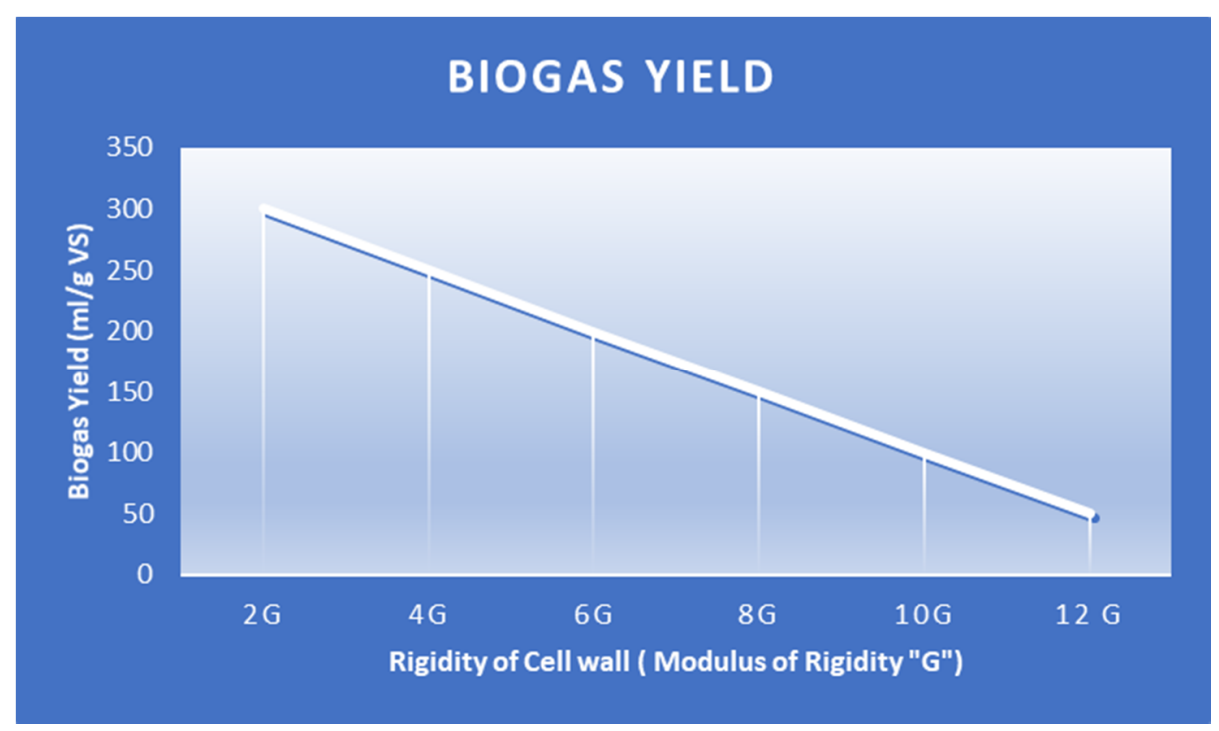

Figure 4. (Rigidity of cell wall in terms of Modulus of Rigidity) Between Biogas yield (ml/g VS along Y-axis) and Microalgal cell wall rigidity (Modulus of Rigidity (G) along X- axis).

This problem can be overcome by abolishing the microalgal cell wall from which intracellular organic or inorganic molecules are given out due to this their solubilization is increased and offer more surface area for dilapidation to bacteria [75]. From this, biogas or methane productivity automatically touched the elevated point [50] (Fig. 05). 


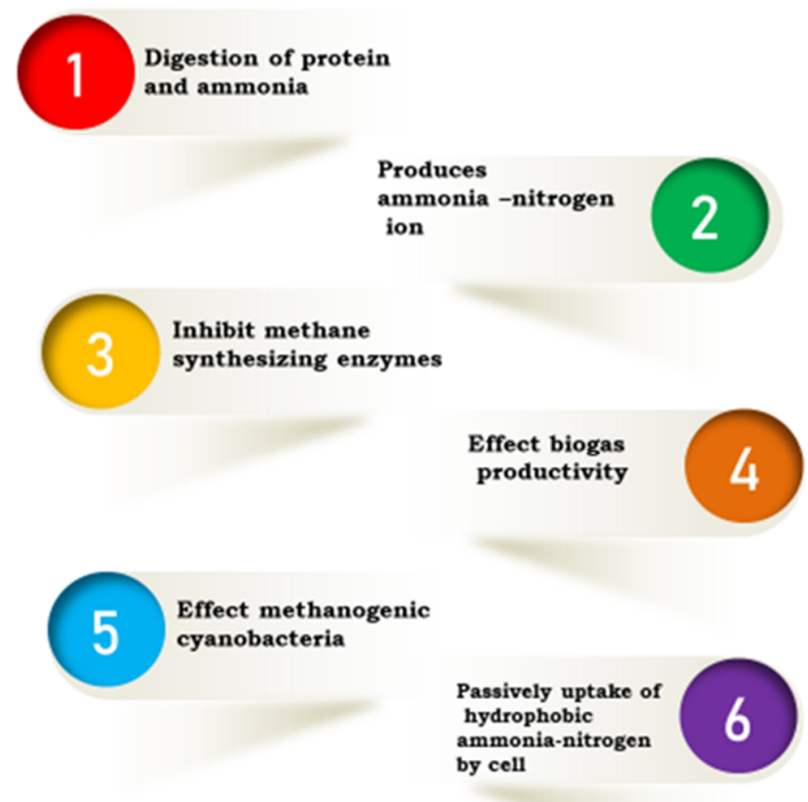

Figure 5 (Solution of Cell wall rigidity for enhancing Biogas Production)

\section{Carbon to Nitrogen Ratio (C: N):}

Carbon to nitrogen ratio boosted the complications for anaerobic digestion of microalgal biomass from this productivity of biogas also affected [76]. If $\mathrm{C} / \mathrm{N}$ ration below the 20 than it fashioned high amount nitrogen in the form of ammonia that source of inhibitory effect on anaerobic digestion that's why nitrogen cause negative effect on biogas productivity indirectly [77] [78]. It can be cracked by harmonising the nutrient number by means of high carbon contents substrate added for digestion that will circumvent ammonia inhibitory effect [77](Fig. 06).

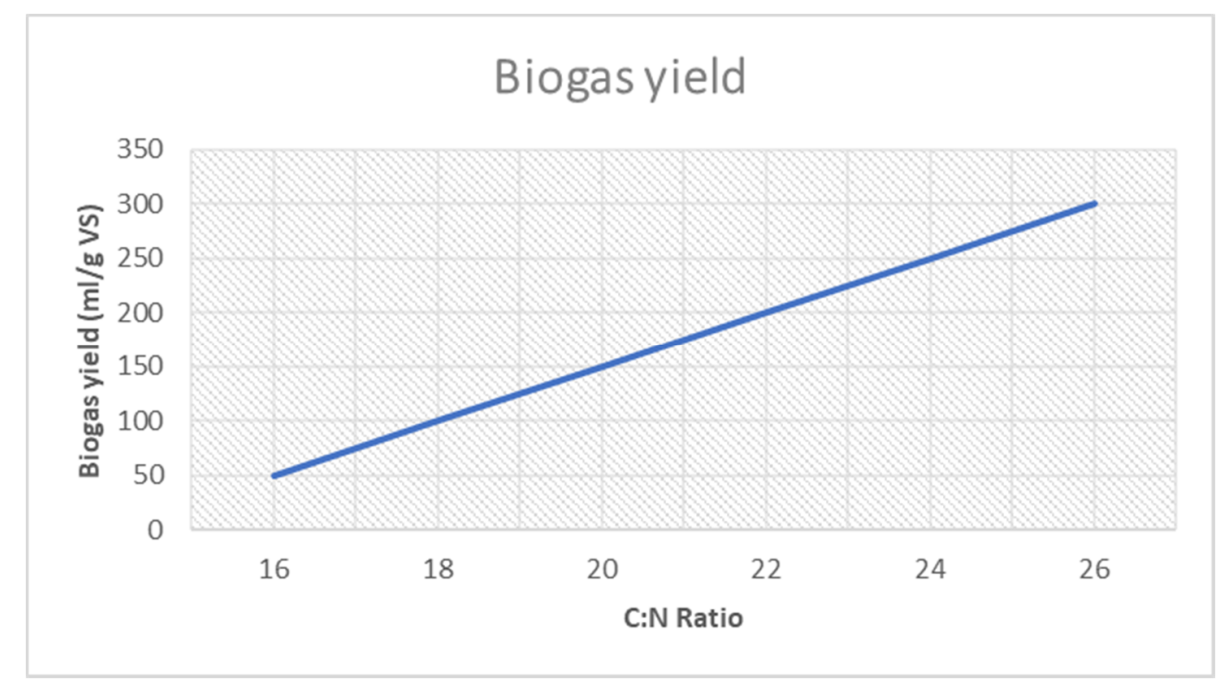

Page 14 of 20 
Figure 6 (Effect of Carbon-Nitrogen Ratio on Biogas Yield)

\section{Ammonia-Nitrogen toxicity:}

By hydrolysis of nitrogen containing compounds (Protein, urea, and Keratin), they give us ammonia nitrogen ions that are impregnated in algal cell also cause ammonia- nitrogen toxicity due to this ammonianitrogen concentration is increased that inhibit many methane synthesizing enzymes or also hydrophobic ammonia-nitrogen can passively pass across cell. Due to movement of ammonia- nitrogen ions can imbalance the potassium concentration and decreased the biogas productivity [71]. This problem must be solved by departure of acetogenic or hydrolytic bacteria at one period and methanogenic bacteria next, but this is also be institute in microbial fuel cell, these cells are valuable for lower the level of ammonia-nitrogen ions that augment the productivity of biogas or also steady the anaerobic digestion. Optimum concentration of ammonia-nitrogen is $3000 \mathrm{mg} / \mathrm{L}$ in a reactor above this figure effect the productivity of Biogas [77](Fig. 07)

\section{Effect of Salinity:}

Microalgae (such as Macrocystis pyrifera and Tetraselmis sp.) are cultivated in saline-habitat to shelter the agriculture land and lower alkaline earth metal are required for better anaerobic digestion in saline environment. Higher concentration of alkaline earth changes the $\mathrm{pH}$ and cause toxicity for methanogenic bacteria. Higher salinity cause dehydration in bacterial cell due to higher osmotic pressure that cause inhibitory effect on digestion. Sodium, aluminium and magnesium change the chemistry of saline environment that must be toxic for anaerobic processing of algal biomass indirectly effect the biogas production [55].

\section{Role of Sulfide:}

Micro-algae in freshwater have less amount of sulfurated amino acid so during digestion production of $\mathrm{H}_{2} \mathrm{~S}$ less but from saline water (marine water) have measurable amount of oxidized sulphide compounds that act as electron acceptor for sulphide reducing bacteria to convert organic compounds into $\mathrm{H}_{2} \mathrm{~S}$ that cause corrosion in apparatus (photobioreactor) due to this extra amount of $\mathrm{H}_{2} \mathrm{~S}$ must be removed from apparatus from which biogas productivity also decreased in result of unworkable apparatus [55].

\section{Conclusion:}

Energy requisition now-a-days touched at higher level resulting in depletion of non-biodegradable resources. That's why truncated energy production effects economic value of any industrial country to overcome this crisis by using algal lignocellulosic biomass undergoes anaerobic digestion. To contract high yield of bioenergy product over exploitation of agro-industrial wastes, wastewater and other enduring biomass that is unsurpassed way to improve economy or to marmalade the natural environment.

\section{List of Abbreviation}

HMF_ Hydro methyl furfurals

AFEX_Ammonia fibre explosion-method

ARP_Ammonia recycling percolation

SAA_Soaking in Aqueous ammonia 
MBWT_Microalgal based wastewater treatment

\section{ETHICS APPROVAL AND CONSENT TO PARTICIPATE}

Not applicable

\section{CONSENT FOR PUBLICATION}

Not applicable

\section{AVAILABILITY OF DATA AND MATERIAL}

Not applicable

\section{COMPETING INTERESTS}

The authors declare that they have no competing interests

\section{FUNDING}

No funding

\section{AUTHORS' CONTRIBUTIONS}

All Authors contributed equally.

\section{ACKNOWLEDGEMENTS}

Not applicable

\section{References:}

1. Khan, N.A. and H. el Dessouky, Prospect of biodiesel in Pakistan. Renewable and Sustainable Energy Reviews, 2009. 13(6-7): p. 1576-1583.

2. Rupprecht, J., From systems biology to fuel--Chlamydomonas reinhardtii as a model for a systems biology approach to improve biohydrogen production. J Biotechnol, 2009. 142(1): p. 10-20.

3. Schenk, P.M., et al., Second generation biofuels: high-efficiency microalgae for biodiesel production. Bioenergy research, 2008. 1(1): p. 20-43.

4. Medipally, S.R., et al., Microalgae as sustainable renewable energy feedstock for biofuel production. Biomed Res Int, 2015. 2015: p. 519513.

5. Parmar, A., et al., Cyanobacteria and microalgae: a positive prospect for biofuels. Bioresource technology, 2011. 102(22): p. 10163-10172.

6. Demirbas, A., Biodiesel. 2008: Springer.

7. Spolaore, P., et al., Commercial applications of microalgae. Journal of bioscience and bioengineering, 2006. 101(2): p. 87-96.

8. Aresta, M., A. Dibenedetto, and G. Barberio, Utilization of macro-algae for enhanced CO2 fixation and biofuels production: Development of a computing software for an LCA study. Fuel processing technology, 2005. 86(14-15): p. 1679-1693.

9. Baltrènas, P. and A. Misevičius, Biogas production experimental research using algae. Journal of Environmental Health Science and Engineering, 2015. 13(1): p. 18.

10. Liu, Z.-Y., G.-C. Wang, and B.-C. Zhou, Effect of iron on growth and lipid accumulation in Chlorella vulgaris. Bioresource technology, 2008. 99(11): p. 4717-4722. 
11. Roberts, K.P., S. Heaven, and C.J. Banks, Comparative testing of energy yields from micro-algal biomass cultures processed via anaerobic digestion. Renewable Energy, 2016. 87: p. 744-753.

12. Mudimu, O., et al., Biotechnological screening of microalgal and cyanobacterial strains for biogas production and antibacterial and antifungal effects. Metabolites, 2014. 4(2): p. 373-393.

13. Karemore, A., M. Nayak, and R. Sen, Recent Inventions and Trends in Algal Biofuels Research. Recent Pat Biotechnol, 2016. 10(1): p. 30-42.

14. Cabral, J., E. Ferreira, and M. Mota, Book of abstracts of the 2nd Meeting of the Institute for Biotechnology and Bioengineering. 2010.

15. Agwa, O., S. Ibe, and G. Abu, Economically effective potential of Chlorella sp. for biomass and lipid production. Journal of Microbiology and Biotechnology Research, 2012. 2(1): p. 35-45.

16. Bajhaiya, A., et al., Algal biodiesel The next generation biofuel for India. Asian J. Exp. Biol. Sci, 2010. 4: p. 728-739.

17. Zhu, C. and Y. Lee, Determination of biomass dry weight of marine microalgae. Journal of applied phycology, 1997. 9(2): p. 189-194.

18. Xiong, W., et al., High-density fermentation of microalga Chlorella protothecoides in bioreactor for microbio-diesel production. Applied microbiology and biotechnology, 2008. 78(1): p. 29-36.

19. $\mathrm{Xu}, \mathrm{H} ., \mathrm{X}$. Miao, and Q. Wu, High quality biodiesel production from a microalga Chlorella protothecoides by heterotrophic growth in fermenters. Journal of biotechnology, 2006. 126(4): p. 499-507.

20. Chisti, Y., Biodiesel from microalgae. Biotechnol Adv, 2007. 25(3): p. 294-306.

21. Jahangir, T., et al., Physico-chemical and biological study of Mangho Pir euthermal springs Karachi, Sindh, Pakistan. Online J. Biol. Sci, 2001. 1: p. 636-639.

22. Zamalloa, C., N. Boon, and W. Verstraete, Anaerobic digestibility of Scenedesmus obliquus and Phaeodactylum tricornutum under mesophilic and thermophilic conditions. Applied Energy, 2012. 92: p. 733-738.

23. Ruiz-Marin, A., L.G. Mendoza-Espinosa, and T. Stephenson, Growth and nutrient removal in free and immobilized green algae in batch and semi-continuous cultures treating real wastewater. Bioresource technology, 2010. 101(1): p. 58-64.

24. Mendez, L., et al., Chlorella vulgaris vs cyanobacterial biomasses: Comparison in terms of biomass productivity and biogas yield. Energy conversion and management, 2015. 92: p. 137-142.

25. Taherzadeh, M.J. and K. Karimi, Pretreatment of lignocellulosic wastes to improve ethanol and biogas production: a review. International journal of molecular sciences, 2008. 9(9): p. 1621-1651.

26. Williams, P.J.1.B. and L.M. Laurens, Microalgae as biodiesel $\mathcal{E}$ biomass feedstocks: review $\mathcal{E}$ analysis of the biochemistry, energetics $\mathcal{E}$ economics. Energy \& Environmental Science, 2010. 3(5): p. 554-590.

27. Marzano, C.M.A.D.S., et al., Biomethanation of the Marine Algae Tetraselmis. International Journal of Solar Energy, 1982. 1(4): p. 263-272.

28. Kulkarni, M.G. and A.K. Dalai, Waste cooking oil an economical source for biodiesel: a review. Industrial \& engineering chemistry research, 2006. 45(9): p. 2901-2913.

29. Quinn, J.C., et al., Microalgae to biofuels: life cycle impacts of methane production of anaerobically digested lipid extracted algae. Bioresource technology, 2014. 171: p. 37-43.

30. Urtubia, H.O., L.B. Betanzo, and M. Vásquez, Microalgae and cyanobacteria as green molecular factories: tools and perspectives. Algae-Organisms for Imminent Biotechnology, 2016: p. 1-27.

31. Konopka, A. and T.D. Brock, Effect of temperature on blue-green algae (cyanobacteria) in Lake Mendota. Appl. Environ. Microbiol., 1978. 36(4): p. 572-576.

32. Gross, M., Development and optimization of algal cultivation systems. 2013.

33. Converti, A., et al., Effect of temperature and nitrogen concentration on the growth and lipid content of Nannochloropsis oculata and Chlorella vulgaris for biodiesel production. Chemical Engineering and Processing: Process Intensification, 2009. 48(6): p. 1146-1151. 
34. Mallick, N., et al., Progress and challenges in microalgal biodiesel production. Frontiers in microbiology, 2016. 7: p. 1019.

35. Ali, A., Z.K. Shinwari, and F.M. Sarim, Contribution to the algal flora (Chlorophyta) of fresh waters of district Swat. NWFP, Pakistan. Pak J Bot, 2010. 42(5): p. 3457-3462.

36. Jehlee, A., P. Khongkliang, and O. Sompong, Biogas Production from Chlorella sp. TISTR 8411 biomass cultivated on biogas effluent of seafood processing wastewater. Energy Procedia, 2017. 138: p. 853-857.

37. Cerón Garcí, M.C., et al., Mixotrophic growth of Phaeodactylum tricornutum on glycerol: growth rate and fatty acid profile. Journal of Applied Phycology, 2000. 12(3): p. 239-248.

38. Munir, N., et al., Optimization of growth conditions of different algal strains and determination of their lipid contents. J Anim Plant Sci, 2015. 25(2): p. 546-553.

39. Chen, F., High cell density culture of microalgae in heterotrophic growth. Trends in biotechnology, 1996. 14(11): p. 421-426.

40. Ravindran, R. and A.K. Jaiswal, A comprehensive review on pre-treatment strategy for lignocellulosic food industry waste: challenges and opportunities. Bioresource technology, 2016. 199: p. 92-102.

41. Teghammar, A., Biogas Production from Lignocelluloses: Pretreatment, Substrate Characterization, CoDigestion and Economic Evaluation. 2013, Chalmers Tekniska Högskola.

42. Karlsson, H., et al., Ethanol production in biorefineries using lignocellulosic feedstock-GHG performance, energy balance and implications of life cycle calculation methodology. Journal of cleaner production, 2014. 83: p. 420-427.

43. Miazek, K., et al., Effect of lignocellulose related compounds on microalgae growth and product biosynthesis: a review. Energies, 2014. 7(7): p. 4446-4481.

44. $\mathrm{Hu}, \mathrm{Q}$., et al., Microalgal triacylglycerols as feedstocks for biofuel production: perspectives and advances. The plant journal, 2008. 54(4): p. 621-639.

45. Hasunuma, T., et al., Development of a GIN11/FRT-based multiple-gene integration technique affording inhibitor-tolerant, hemicellulolytic, xylose-utilizing abilities to industrial Saccharomyces cerevisiae strains for ethanol production from undetoxified lignocellulosic hemicelluloses. Microbial cell factories, 2014. 13(1): p. 145.

46. Howard, R., et al., Lignocellulose biotechnology: issues of bioconversion and enzyme production. African Journal of biotechnology, 2003. 2(12): p. 602-619.

47. Isikgor, F.H. and C.R. Becer, Lignocellulosic biomass: a sustainable platform for the production of biobased chemicals and polymers. Polymer Chemistry, 2015. 6(25): p. 4497-4559.

48. Vanholme, R., et al., Lignin biosynthesis and structure. Plant physiology, 2010. 153(3): p. 895-905.

49. Qin, C., K. Clarke, and K. Li, Interactive forces between lignin and cellulase as determined by atomic force microscopy. Biotechnology for biofuels, 2014. 7(1): p. 65.

50. González-Fernández, C., et al., Effect of organic loading rate on anaerobic digestion of thermally pretreated Scenedesmus sp. biomass. Bioresource technology, 2013. 129: p. 219-223.

51. Ahmad, S., et al., Prospects for pretreatment methods of lignocellulosic waste biomass for biogas enhancement: opportunities and challenges. Biofuels 1-20. htt p s. doi. org/10.1080/1759, 2017. 7269(2017): p. 1378.

52. Wi, S.G., et al., Lignocellulose conversion for biofuel: a new pretreatment greatly improves downstream biocatalytic hydrolysis of various lignocellulosic materials. Biotechnology for biofuels, 2015. 8(1): p. 228.

53. Manzoor, M., et al., Microalgal-bacterial consortium: a cost-effective approach of wastewater treatment in Pakistan. Punjab University Journal of Zoology, 2016. 31(2): p. 307-320.

54. Kong, Q.-x., et al., Culture of microalgae Chlamydomonas reinhardtii in wastewater for biomass feedstock production. Applied biochemistry and Biotechnology, 2010. 160(1): p. 9.

55. Sharma, S., Algae Energy: A Perspective on Algae as a Biogas source in Nordic Climate. 2017. 
56. Salerno, M., Y. Nurdogan, and T.J. Lundquist, Biogas production from algae biomass harvested at wastewater treatment ponds. 2009: American Society of Agricultural and Biological Engineers.

57. Mahapatra, D.M., H. Chanakya, and T. Ramachandra, Treatment efficacy of algae-based sewage treatment plants. Environmental monitoring and assessment, 2013. 185(9): p. 7145-7164.

58. Bhatnagar, A., et al., Chlorella minutissima - a promising fuel alga for cultivation in municipal wastewaters. Applied biochemistry and biotechnology, 2010. 161(1-8): p. 523-536.

59. Manzoor, M., et al., Lucrative future of microalgal biofuels in Pakistan: a review. International Journal of Energy and Environmental Engineering, 2015. 6(4): p. 393-403.

60. Li, Y., et al., Characterization of a microalga Chlorella sp. well adapted to highly concentrated municipal wastewater for nutrient removal and biodiesel production. Bioresource technology, 2011. 102(8): p. 5138-5144.

61. Spolaore, P., et al., Commercial applications of microalgae. J Biosci Bioeng, 2006. 101(2): p. 87-96.

62. Newsted, J.L., Effect of light, temperature, and $p H$ on the accumulation of phenol by Selenastrum capricornutum, a green alga. Ecotoxicology and environmental safety, 2004. 59(2): p. 237-243.

63. Órpez, R., et al., Growth of the microalga Botryococcus braunii in secondarily treated sewage. Desalination, 2009. 246(1-3): p. 625-630.

64. Golueke, C.G., W.J. Oswald, and H.B. Gotaas, Anaerobic digestion of algae. Applied microbiology, 1957. 5(1): p. 47.

65. Janssen, M., et al., Specific growth rate of Chlamydomonas reinhardtii and Chlorella sorokiniana under medium duration light/dark cycles: 13-87 s. Journal of biotechnology, 1999. 70(1-3): p. 323-333.

66. Batista, A.P., L. Gouveia, and I.P.R. Marques. Scenedesmus obliquus: biogas production from residues of biodiesel/bioethanol extraction processes [Resumo]. in 2nd International Conference on Algal Biorefinery: A potential source of food, feed, biochemicals, biofuels and biofertilizers. 2014.

67. Hasunuma, T., et al., Development of a GIN11/FRT-based multiple-gene integration technique affording inhibitor-tolerant, hemicellulolytic, xylose-utilizing abilities to industrial Saccharomyces cerevisiaestrains for ethanol production from undetoxified lignocellulosic hemicelluloses. Microbial cell factories, 2014. 13(1): p. 145.

68. Sakai, S., et al., Effect of lignocellulose-derived inhibitors on growth of and ethanol production by growtharrested Corynebacterium glutamicum R. Appl. Environ. Microbiol., 2007. 73(7): p. 2349-2353.

69. Jönsson, L.J., B. Alriksson, and N.-O. Nilvebrant, Bioconversion of lignocellulose: inhibitors and detoxification. Biotechnology for biofuels, 2013. 6(1): p. 16.

70. Karlsson, A., et al., Improvement of the Biogas Production Process: Explorative project (EP1). 2014, Linköping University Electronic Press.

71. Murphy, J.D., et al., A perspective on algal biogas. 2015: IEA Bioenergy.

72. Mussgnug, J.H., et al., Microalgae as substrates for fermentative biogas production in a combined biorefinery concept. Journal of biotechnology, 2010. 150(1): p. 51-56.

73. Jankowska, E., A.K. Sahu, and P. Oleskowicz-Popiel, Biogas from microalgae: Review on microalgae's cultivation, harvesting and pretreatment for anaerobic digestion. Renewable and Sustainable Energy Reviews, 2017. 75: p. 692-709.

74. Bohutskyi, P., M.J. Betenbaugh, and E.J. Bouwer, The effects of alternative pretreatment strategies on anaerobic digestion and methane production from different algal strains. Bioresource technology, 2014. 155: p. 366-372.

75. Prajapati, S.K., et al., Enhanced methane production from algal biomass through short duration enzymatic pretreatment and codigestion with carbon rich waste. RSC Advances, 2015. 5(82): p. 6717567183.

76. Hossain, A.S., et al., Biodiesel fuel production from algae as renewable energy. American journal of biochemistry and biotechnology, 2008. 4(3): p. 250-254. 
77. Ward, A., D. Lewis, and F. Green, Anaerobic digestion of algae biomass: a review. Algal Research, 2014. 5: p. 204-214.

78. Neumann, P., et al., Anaerobic co-digestion of lipid-spent microalgae with waste activated sludge and glycerol in batch mode. International Biodeterioration \& Biodegradation, 2015. 100: p. 85-88. 